DOI: 10.52363/passa-2021.1-5

UDC: 351

Lopatchenko Inna, PhD of Public administration, lecturer at the Training and Research and Production center, National university of civil defence of Ukraine, Kharkiv,

ORCID ID: 0000-0002-4838-2154

Batyr Yurij, PhD of Economic Sciences, associate professor, National university of civil defence of Ukraine, Kharkov,

ORCID ID: 0000-0002-4838-2154

Krutii Olena, Doctor of Science in Public Administration, Professor of the Department of Political Science and Philosophy of KRI NAPA, the city of Kharkiv.

ORCID ID: 0000-0002-5180-2842

\title{
ACTUAL MECHANISMS FOR THE DEVELOPMENT OF CORPORATE AND MANAGERIAL CULTURE IN PUBLIC ADMINISTRATION
}

The modern dimensions of corporate and managerial culture development in public administration in Ukraine has been justified. Corporate and managerial culture development is highlighted in particular different approaches. It is emphasized that the effectiveness of mechanisms in cultural modernization of public administration in Ukraine is a combination of objective (organizational-legal) and subjective (socio-psychological) components in development of corporate culture in public management. Objective components are analyzed, which provide for regulatory, structural, functional and methodological ordering the activities of state structures, taking into account the factors of corporate culture development. Subjective components have been shown to ensure the multidimensionality of communication tools. The basic characteristics of an innovative 
corporate culture such as knowledge, information, creativity and institutionalization are highlighted. It is proved that innovative corporate culture contributes to changing the status of professional activity of public servants, from managerial-controlling (powerinfluence), to consciously subordinate to the needs of citizens (power-interaction), and secondly to protect the culture of public administration from destructive influence global values and also the mobilization of public servants; and the public; consciousness towards engagement and mutual responsibility.

Key words: public administration, corporate culture, managerial culture, development

In the first stages of management development, the phenomenon of corporate culture was formed and used mainly to enhance the aspects of management and optimization of production processes. Over time, the trend of strategic influence of corporate culture on the formation of new models of management, values and norms, group and interpersonal communication, etc., was revealed. That is why the question of contemporary priorities and prospects of development of corporate culture of public administration in modern Ukraine becomes relevant. A lot of aspects of the influence of corporate culture and its dependence on the factors of internal and external organizational environment, emphasize the inability to invent a single correct for all conditions algorithm for corporate culture management of public management. It has been proved that its key basis should be the process of reconciling the constituent elements of organizational culture with the strategic goals of a particular public authority, with its structure and staff, with the specific features of public activity and its situational context and with the general philosophy of public management.

In public management studies, different approaches to corporate culture can be identified. Some propose a conceptual model of public administration that should express the desire of the authorities and civil society for cooperation and parity. Others emphasize factors that are decisive in the prospective processes of corporate culture transformation in public administration. This is the basis for determining the strategic priorities for the development of a new corporate culture of public administration. O. Krutyi's research 
about the mechanism of dialogue interaction between the institutions of power and the public in modern Ukraine proves that in most cases the interaction is limited by formal contacts between the authorities and members of the public. Improvement of this process is possible due to the development of conceptual models of dialog interaction at the socioinstitutional and interpersonal levels, in the systematization of modern social and psychological technologies in the dialogue of public administration on the basis of symmetry of positions, autonomy, mutual understanding and creative development of output .[3]. This approach is the basis of the new philosophy and contemporary priorities for the development of a corporate culture of public administration.

The author has been proposed a conceptual model of public administration, according to which it is necessary to create objective conditions for the existence of dialogic forms of interaction between the authorities and the public and to consolidate them in the relevant legislative, economic, organizational, information forms. A necessary condition for the viability of the model is the development and implementation of programs for the formation of subjects' psychological readiness for dialogue interaction. Thus, this conceptual model encompasses two sides of the process of dialogue interaction - at the level of institutional interaction of authorities and civil society and at the interpersonal level [3, p. 216].

As the author emphasizes, such a model should be an expression of the desire of the authorities and civil society to cooperate in order to develop a new corporate culture of public administration. This implies the creation of a flexible management system and the application of effective administrative management methods instead of the usual bureaucratic procedures, which places new demands on the training of public administration entities. Creativity, ability to engage in dialogue and collaboration should be the basis for the professional competence of employees and the new corporate culture of public administration as a whole. One of the tools for implementing this is the creation of psychological assessment centers (assessment centers), which comprehensively solves the tasks of both diagnostics and the development of a new corporate culture of public administration [3]. 
Based on this, we can determine the effectiveness of mechanisms of cultural modernization of public administration in Ukraine, which is a combination of objective (organizational-legal) and subjective (socio-psychological) components of the development of corporate culture of public management. The objective components ensure the orderliness and coherence of the activities of such state structures, as well as a substantive refinement of relevant laws and other legal acts, taking into account the corporative culture of public administration. The subjective components are to provide a lot of dimension to the communication tools.

Considering the above, the following can be distinguished to the strategic priorities for the development of corporate culture of public administration in Ukraine:

1) the improvement of the organizational and legal component of the mechanism of development of corporate culture, which provides for structural transformations in the activity of public authorities, namely to restore the general and social character of a permanent body acting at the national level and creating a permanent body that would provide productive social dialogue. The establishment of special institutions at the regional level is important for establishing a full-fledged development of the corporate culture of public administration in Ukraine.

2) adequate functioning of the mechanisms of development of the corporate culture of public administration in Ukraine requires an adequate change not only in the structure but also in the methodology of activity of the state authorities of Ukraine. Yes, it is necessary to create the right conditions to ensure the realization of the right of every person, to move from punitive functions to full support and protection. Achieving this goal requires a number of important tasks.

3) the establishment of an effective dialogue between public authorities and the public. Such dialogue is necessary to improve the social and psychological component of the corporate culture development mechanism.

It is also very important to develop the corporate culture of public administration as a key factor in the mass culture of society, taking into account the changing external environment. This is especially important in the context of 21 st century governance, based 
on social innovation to limit the destructive influence of global values, norms, standards of interpersonal and group interaction. In this regard, Ukraine has been faced with the question of the introduction of innovative technologies in the activities of public authorities. Some states have already proven from their own experience that the introduction of innovations reduces the cost of maintaining the state apparatus and improves its performance. Given the current review of the functions of the authorities in the context of the implementation of the idea of a service state, continuous development and innovative transformations in accordance with the requirements of today, a system of public service provision is required.

Accordingly, an important aspect of the analysis is the systematic development of problems of ensuring the integrity of the organizational and managerial context of the functioning and development of the organizational activity of the personnel of the authorities. In this context, the processes of formation and development of an appropriate corporate culture as a strategic factor of stimulating the innovative activity of public servants in their professional activity, which is aimed primarily at providing quality services to the population, are of particular relevance. C Gaiduchenko stresses that one of the most important factors for the success of an organization in modern conditions is knowledge, and they are closely linked to the development of its culture. Knowledge management becomes one of the factors of time-based culture and is one of the basic prerequisites for the success of public administration reforms [2].

In addition to the strategic priorities of corporate governance development outlined above, there is a study of national authors, which emphasizes four factors that are complex in perspective processes of corporate culture transformation in public administration. These are the factors of knowledge, information, innovation and institutionalization that are considered in relation to and interrelated between the constituent elements of the organizational culture of public administration.

The managerial and especially the motivational component are the most significant and thanks to them all the components of the corporate culture of public administration are realized. It is well known that in order to effectively manage the development of 
organizational culture it is necessary to clearly define the purpose of managerial influence, which is directly related to the mission and strategy of the organization. This can be not only the formation and development of organizational culture, but also its stabilization (retention of existing characteristics), for example, in the highest phase of the organizational life cycle, or, conversely, urgent (unpredictable) changes in the characteristics of organizational culture that have acquired destructive content.

An important reason for the inadequate level of the managerial component of the organizational culture of public management of the requirements of society, of course, is its motivational component. It cannot be said that it is not improved, but this improvement is limited by unpromising methods, without interaction with other regulatory components (knowledge, information, creativity and institutionalization), as well as constructive (value, normative, information and communication, corporate) control [2].

Appropriate changes in corporate culture can contribute to the formation of a new social status of professional activity of public servants, changing their consciousness from managerial control (power-influence), to conscious subordination to the needs of citizens (power-interaction). In this sense, the activity of public servants acquires a more pronounced professional character, since it is directed not at the process, but at its result, which is evaluated by the citizens.

In such circumstances, one of the central indicators of the professionalism of a civil servant or official is innovative activity - the ability to generate new ideas, develop innovations, display creativity and civic responsibility for their activities, etc. In order to facilitate the development of employees' innovative activity, it is necessary to introduce knowledge-based innovation in public management. The development of the innovative culture of society involves the support of the national book publishing, educational and popular science editions, development of educational and popular science programs in mass media, distance learning centers using modern telecommunication technologies, modern computer technologies for teaching and scientific processes. [2].

Studies by foreign and domestic authors have provided a basis for determining the following characteristics of an innovative corporate culture: a focus on higher standards of achievement and quality; support of talents; tolerance and respect for the individual, commitment to support the autonomous actions of employees; an atmosphere of 
encouragement of new ideas and freedom of expression; active knowledge management models; openness of organizational communications; willingness to take risks; an adhocratic model of organizational leadership as well as distributed leadership in teams; active involvement of external stakeholders in the management process; attentiveness to the end result and intense feedback" $[2]$.

Some authors add to the list of characteristics of an innovative corporate culture the qualities of an information culture of public administration. These are the additional features, the most modern active models of information management; conformity of the organizational structure of the letter and spirit of organizational culture; openness, understanding and support of the organization's mission execution strategies at various levels of governance and coordination; an active and democratic model of legislative creativity; predominantly Adhocratic type of organizational culture with possible markettype features; the participative and flexible nature of management forms of both corporate culture and organizational structure.

In addition, a distinctive feature of innovative corporate culture is such a characteristic as civic responsibility, which summarizes the end result of risks and their total prudence with regard to civil society, which, in turn, will emphasize the specificity of public activity.

Thus, in the aggregate, the characteristics of an innovative corporate culture will contribute, first, to the mobilization of the consciousness of public servants and the public to achieve the goals of regional and local innovation development, and secondly, to the formation of a culture of public administration against the destructive influence of global values, which is not always conducive to in a society of freedom, equality and justice. This can be destructive.

Transformational processes and organizational and structural changes of the modern Ukrainian statehood are connected with both internal and external factors. However, its key factors are the transformation of public administration and civil society in a socio-cultural context. In order for these processes to be understood and predictable, the prospects for their development should be considered in relation to the development of the corporate culture of public administration. 
As a conclusion, it is worth noting that the current dimensions of the development of corporate culture of public administration in Ukraine are directly related to the transformation processes of public administration itself, as well as to the development of civil society as a social system. Strategic priorities for the development of corporate culture of public administration in Ukraine include improvement of the organizational and legal component of the mechanism of development of corporate culture, which implies structural transformations in the activity of public authorities, change in the methodology of activity of public authorities of Ukraine, transition from the use of punitive functions to full support and protection and establishment of effective dialogue between public authorities and the public. At the same time, the tendency of the strategic influence of the corporate culture on the formation of new models of consumption of values and norms, group and interpersonal communication, stimulation of innovative activity of public servants in their professional activity, which aims, above all, at providing quality services to the population, undoubtedly, undoubtedly, becomes evident. improvement of corporate culture is the key to effective functioning of the organization and development of civil society culture.

\section{References}

1. Anishhenko, V. O. (2009). "Rol' korporatyvnoi kul'tury v pryjnyatti upravlinskych rishen", ["The role of Corporate Culture in Managerial Decision-making"], journal Aktualni problemy ekonomiky [Current problems of the economy], vol. 3, 64-71. [Ukraine]

2. Gaiduchenko S. O. (2016) Orhanizatsijna kul'tura u konteksti publichnoho upravlinnia [Organizational culture in the context of public administration], Monograph, Press Madrid, Kharkiv, 344 p. [Ukraine]

3. Krutiy O. M. (2008) Dialohova vzayemodiya orhaniv derzhavnoyi vlady ta hromads'kosti [Dialogue interaction between public authorities and the public], Monograph, Press Magistr, Kharkiv, 236 p. [Ukraine]

4. Spyvak,V. A. (2001). Korporatyvnaya kultura [Corporate Culture], Tutorial, Pyter, SanktPeterburg, $352 \mathrm{p}$.

5. Shevchenko, V. S. (2011). "Vyznachennya vplyvu korporatyvnoyi kultury na diyalnist pidpryyemstva" [Determining of the impact of corporate culture on the enterprise], journal Komunalne gospodarstvo [Utilities], vol. 14, 160-165. [Ukraine] 